\title{
Reproductive traits of the yellow-mandi catfish \\ Pimelodus maculatus Lacépède \\ (Osteichthyes, Siluriformes) in captive breeding
}

\author{
Yoshimi Sato ${ }^{1}$ \\ Nelsy Fenerich-Verani ${ }^{2}$ \\ José Roberto Verani ${ }^{2}$ \\ Hugo Pereira Godinho ${ }^{3}$ \\ Edson Vieira Sampaio ${ }^{1}$
}

\begin{abstract}
Pimelodus maculatus Lacépède, 1803 is an important fish of the São Francisco river basin, where it is economically significant in both professional and sports fisheries. The fish, maintained in captivity, was subjected to hypophysation with crude carp pituitary extract. Approximately $70 \%$ of the females treated spawned viable eggs. The eggs were opaque, demersal, yellow and free. Egg stripping was performed at 213 hour-degrees (duration $=8.3 \mathrm{~h}$ ) after the second dose injection, at water temperature of $25-26^{\circ} \mathrm{C}$. Hatching occurred at 394 hour-degrees (duration $=16.3 \mathrm{~h}$ ) after egg fertilization, at water temperature of $24-25^{\circ} \mathrm{C}$. Egg fertilization rate was $64.8 \%$. The relationship between absolute fecundity (AF), initial fertility (IF) and final fertility (FF) and body weight are expressed, respectively, by $\mathrm{AF}=-331+181717$ $\mathrm{Wt}\left(\mathrm{r}^{2}=0.62\right), \mathrm{IF}=-16839+158123 \mathrm{Wt}\left(\mathrm{r}^{2}=0.65\right)$, and $\mathrm{FF}=-9874+100365 \mathrm{Wt}$ $\left(r^{2}=0.63\right)$.
\end{abstract}

KEY WORDS. Siluriformes, Pimelodus maculatus, yellow-mandi catfish, reproduction

The yellow-mandi catfish Pimelodus maculatus Lacépède, 1803 [= Pimelodus clarias (Bloch, 1782)] is one of the principal species in the professional fisheries of the São Francisco river basin. It can reach 40 to $50 \mathrm{~cm}$ total length, and 1.5 to 2 $\mathrm{kg}$ body weight (IHERING \& WRIGHT 1935). This species is widely distributed and can be found in several South American river basins (FowLER 1951).

Despite the interest it has been sparked in several fields of the fisheries science, its reproduction is little understood. CARDOSO (1934) demonstrated the stimulating action of hypophysis administration on the sexual organs of $P$. clarias, noting a significant increase in the volume of the ovaries and testes. FENERICH et al. (1974) obtained spontaneous ovulation of $P$. maculatus in aquarium using human chorionic gonadotrophin (HCG) associated to a hypophysis suspension.

1) Estaçäo de Hidrobiologia e Piscicultura de Três Marias, Covevasf. Caixa Postal 11, 39205-000 Três Marias, Minas Gerais, Brasil.

2) Departamento de Hidrobiologia, Universidade Federal de São Carlos. Caixa Postal 676, 13565-905 São Carlos, São Paulo, Brasil.

3) Instituto de Ciências Biológicas, Universidade Federal de Minas Gerais. Caixa Postal 486, 30161-970 Belo Horizonte, Minas Gerais, Brasil. 
This study presents data obtained with hypophysation of $P$. maculatus of the São Francisco river basin, at the Três Marias Hydrobiology and Hatchery Station, Companhia de Desenvolvimento do Vale do São Francisco - CODEVASF, during the reproduction cycles of 1995/96 and 1996/97.

\section{MATERIAL AND METHODS}

For this study 22 males and 27 females from the São Francisco River were used. They were stocked for 2 to 3 years in a $200 \mathrm{~m}^{2}$ pond, at the density of $1 \mathrm{~kg}$ of fish $/ 6 \mathrm{~m}^{2}$. The fish were fed with pelletized feed ( $22 \%$ crude protein), at the proportion of $1.5 \%$ of their body weight/day, 5 days/week.

During treatment the brooders were placed in a $3 \times 1 \times 0.8 \mathrm{~m}$ brick-linned tank whose water was kept at $25-26^{\circ} \mathrm{C}$. The method employed to induce spawning was the hypophysation (IHERING et al. 1935; IHERING 1937), using crude common carp pituitary extract (CCPE). The application of CCPE injections, the moment of oocyte extrusion (in hour-degrees), and the rate of fertilization (estimated after clousure of the blastopore) followed the methods described by WOYNAROVICH \& HORVÁTH (1980). The injections were applied intramuscularly close to the dorsal fin. Fertilization was performed "dry" and the eggs placed in 20-liter, funnel type incubators.

The following data was obtained from the females: total length $(\mathrm{Lt}, \mathrm{cm})$, body weight $(\mathrm{Wt}, \mathrm{g})$, Fulton's condition factor $\left(\mathrm{K}=\mathrm{Wt} .100 / \mathrm{Lt}^{3}\right)$, weight of the extruded oocytes (ova, g), number of extruded oocytes/g of ova, weight of the non-extruded oocytes $(\mathrm{g})$, diameter of the fresh non-hydrated and hydrated eggs $(\mu \mathrm{m})$, diameter of the yolk sac $(\mu \mathrm{m})$, width of the perivitelline space $(\mu \mathrm{m})$, thickness of the chorion $(\mu \mathrm{m})$, rate of egg fertilization (estimated after closing of the blastopore), weight of the gonads ( $\mathrm{Wg}=$ weight of extruded oocytes + weight of ovaries after extrusion, g), gonadosomatic index $(\mathrm{GSI}=\mathrm{Wg} .100 / \mathrm{Wt}, \%)$, absolute fecundity (AF), initial (IF) and final (FF) fertility (respectively, the number of extruded oocytes and the number of viable eggs after blastopore closing), and length of the newly hatched larvae $(\mu \mathrm{m})$. Relative fecundity, relative initial fertility, and relative final fertility were estimated in relation to the total length and body weight of the females.

\section{RESULTS AND DISCUSSION}

The reproductive period of this species extends between November and February. Selection of brooders was not easily performed. Although the females presented a more protruding and reddish urogenital papillae, the males did not release semen or only a few droplets when subjected to abdominal pressure. The female average body weight was well above that of the males (688 g and $305 \mathrm{~g}$, respectively). The main results of the present study are summarized in table I.

The females did not signaled the moment of ovulation as it often happens in other species, i.e., Schizodon knerii (Steindachner, 1875); Prochilodus marggravii (Walbaum, 1792) (SATO et al. 1996a, b).

Of the 27 hypophysed females, $19(70.4 \%)$ responded positively to the treatment by releasing viable eggs. The extrusion of oocytes was performed at 213 
\pm 4 hour-degrees (duration $=8.3 \mathrm{~h}$ ) after application of the second dose of CCPE, at water temperature of $25.8 \pm 0.3^{\circ} \mathrm{C}$. The males were sacrificed and had their testes removed and squeezed through a fine cloth (mesh circa $100 \mu \mathrm{m}$ ) over the mass of oocytes.

Table I. Reproductive aspects of yellow-mandi catfish Pimelodus maculatus subjected to hypophysation at Três Marias Hydrobiology and Hatchery Station during the reproduction cycles of 1995/96 and 1996/97. (N) Number of observations, (CCPE) crude common carp pituitary extract, (SD) standard deviation, (CV) coefficient of variation.

\begin{tabular}{|c|c|c|c|c|c|c|}
\hline Parameters & $\mathrm{N}$ & \multicolumn{2}{|c|}{ Mean \pm SD } & $\mathrm{CV}$ & \multicolumn{2}{|c|}{ Range } \\
\hline \multicolumn{7}{|l|}{ Males } \\
\hline Total length ( $\mathrm{Lt}, \mathrm{cm})$ & 22 & $32.10 \pm$ & 1.70 & 5.20 & $29.500 \pm$ & 35.00 \\
\hline Body weight $(\mathrm{Wt}, \mathrm{g})$ & 22 & $305.20 \pm$ & 50.50 & 16.50 & $216.000 \pm$ & 370.20 \\
\hline Single dose (mg CCPE/Kg Wt) & 22 & $2.80 \pm$ & 0.30 & 9.20 & $2.500 \pm$ & 3.00 \\
\hline \multicolumn{7}{|l|}{ Females } \\
\hline Total length $(\mathrm{Lt}, \mathrm{cm})$ & 19 & $38.70 \pm$ & 2.00 & 5.20 & $34.500 \pm$ & 41.50 \\
\hline Fulton's condition factor $(K)$ & 19 & $1.17 \pm$ & 0.12 & 10.43 & $0.880 \pm$ & 1.36 \\
\hline Body weight $(\mathrm{Wt}, \mathrm{g})$ & 19 & $688.00 \pm$ & 150.00 & 22.00 & $451.000 \pm$ & 938.00 \\
\hline \multicolumn{7}{|l|}{ Dosage (mg CCPE/Kg Wt) } \\
\hline First dose & 19 & $0.90 \pm$ & 0.10 & 10.20 & $0.800 \pm$ & 1.00 \\
\hline Second dose & 19 & $5.70 \pm$ & 0.50 & 7.90 & $5.000 \pm$ & 6.00 \\
\hline Interval between doses $(\mathrm{h})$ & 19 & $14.30 \pm$ & 0.70 & 4.70 & $13.000 \pm$ & 15.00 \\
\hline Hour-degrees at stripping & 19 & $213.00 \pm$ & 4.00 & 2.00 & $205.000 \pm$ & 220.00 \\
\hline Water temperature at stripping $\left({ }^{\circ} \mathrm{C}\right)$ & 19 & $25.80 \pm$ & 0.30 & 1.10 & $25.000 \pm$ & 26.00 \\
\hline Gonadosomatic index (GSI, \%) & 19 & $5.53 \pm$ & 0.76 & 13.76 & $4.590 \pm$ & 7.19 \\
\hline Ova weight. $100 / \mathrm{Wt}(\%)$ & 19 & $4.04 \pm$ & 0.68 & 16.96 & $3.080 \pm$ & 5.55 \\
\hline Eggs/g ova (n) & 19 & $3,276.00 \pm$ & 181.00 & 6.00 & $3,023.000 \pm$ & $3,592.00$ \\
\hline \multicolumn{7}{|l|}{ Size of egg $(\mu \mathrm{m})$} \\
\hline Diameter of non-hydrated egg & $120^{*}$ & $1,113.92 \pm$ & 37.02 & 3.32 & $1,052.520 \pm$ & $1,202.88$ \\
\hline Diameter of hydrated egg & $120^{*}$ & $1,838.15 \pm$ & 61.53 & 3.35 & $1,729.140 \pm$ & $1,954.68$ \\
\hline Diameter of yolk sac & $120^{*}$ & $694.13 \pm$ & 45.57 & 6.57 & $626.500 \pm$ & 776.86 \\
\hline Width of perivitelline space & $120^{*}$ & $323.71 \pm$ & 44.28 & 13.68 & $225.540 \pm$ & 413.49 \\
\hline Thickness of chorium & $120^{\star}$ & $248.30 \pm$ & 32.97 & 13.28 & $200.480 \pm$ & 300.72 \\
\hline Egg fertilization rate $(\%)$ & 19 & $64.80 \pm$ & 9.50 & 14.70 & $51.400 \pm$ & 83.50 \\
\hline Absolute fecundity (AF) & 19 & $124,690.00 \pm 3$ & $4,457.00$ & 28.00 & $80,120,000 \pm 2$ & $05,256.00$ \\
\hline Initial fecundity (IF) & 19 & $91,949.00 \pm 2$ & $9,372.00$ & 32.00 & $51,374.000 \pm$ & $58,462.00$ \\
\hline Final fecundity (FF) & 19 & $59,177.00 \pm 1$ & $9,049.00$ & 32.00 & $27,074.000 \pm$ & $91,324.00$ \\
\hline Relative AF (eggs $/ \mathrm{kg}$ of female) & 19 & $181,340.00 \pm 2$ & $8,480.00$ & 16.00 & $142,824.000 \pm 2$ & $54,976.00$ \\
\hline Relative IF (stripped eggs $/ \mathrm{kg}$ of female) & 19 & $132,325.00 \pm 2$ & $4,660.00$ & 19.00 & $94,265.000 \pm$ & $96,847.00$ \\
\hline Relative FF (viable eggs/kf of female) & 19 & $85,377.00 \pm 1$ & $3,882.00$ & 20.00 & $49,678.000 \pm$ & $12,468.00$ \\
\hline Relative AF (eggs/cm of female) & 19 & $3,194.00 \pm$ & 765.00 & 24.00 & $2,226.000 \pm$ & $5,131.00$ \\
\hline Relative IF (stripped eggs/cm of female) & 19 & $2,350.00 \pm$ & 666.00 & 28.00 & $1,427.000 \pm$ & $3,962.00$ \\
\hline Relative FF (viable eggs/cm of female) & 19 & $1,513.00 \pm$ & 433.00 & 29.00 & $752.000 \pm$ & $2,283.00$ \\
\hline Hour-degrees at hatching & 19 & $394.00 \pm$ & 9.00 & 2.00 & $380.000 \pm$ & 410.00 \\
\hline Water temperature at hatching $\left({ }^{\circ} \mathrm{C}\right)$ & 19 & $24.20 \pm$ & 0.40 & 1.70 & $24.000 \pm$ & 25.00 \\
\hline Lt of hatched larvae $(\mu \mathrm{m})$ & $120^{*}$ & $2,607.84 \pm$ & 45.97 & 1.76 & $2,531.060 \pm$ & $2,706.48$ \\
\hline
\end{tabular}

$\left.{ }^{*}\right)$ Refers to measurements taken from six females (20 eggs or 20 larvae/female).

Pimelodus maculatus eggs are opaque, demersal, yellow, and free, with an external membrane surrounding them as a jelly-coat. There are $3276 \pm 181$ oocytes/g of ova. IHERING \& AZEVEDO (1936) registered a jelly-coat on the eggs of Pimelodella lateristriga (Müeller \& Troschel, 1849), which was impregnated by detritus. Similar jelly-coat was also observed in Rhamdia hilarii (Valenciennes, 1840) (GodinHo et al. 1975) and in Rhamdia sapo (Cuvier \& Valenciennes, 1840) (ESPINACH Ros et al. 1984). After hydration, egg diameter increased from 1113.92 $\pm 37.02 \mu \mathrm{m}$ to $1838.15 \pm 61.53 \mu \mathrm{m}$, corresponding to 4.5 times the original volume. 


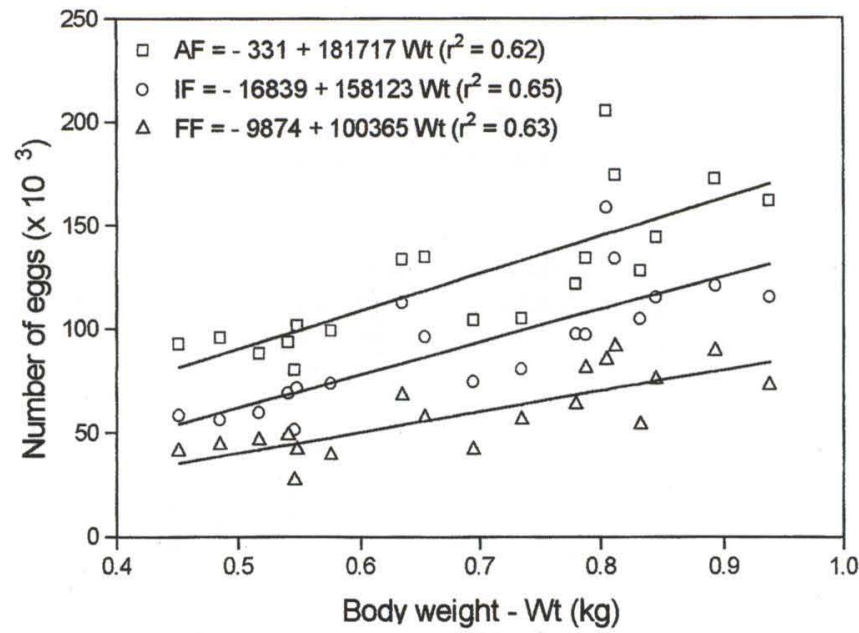

Fig. 1. Linear relationship of absolute fecundity (AF), initial fertility (IF) and final fertility (FF) rates to variations in body weight $(\mathrm{Wt})$, obtained simultaneously from 19 Pimelodus maculatus females subjected to hypophysation at Trs Marias Hydrobiology and Hatchery Station during the reproduction cycles of 1995/96 and 1996/97.

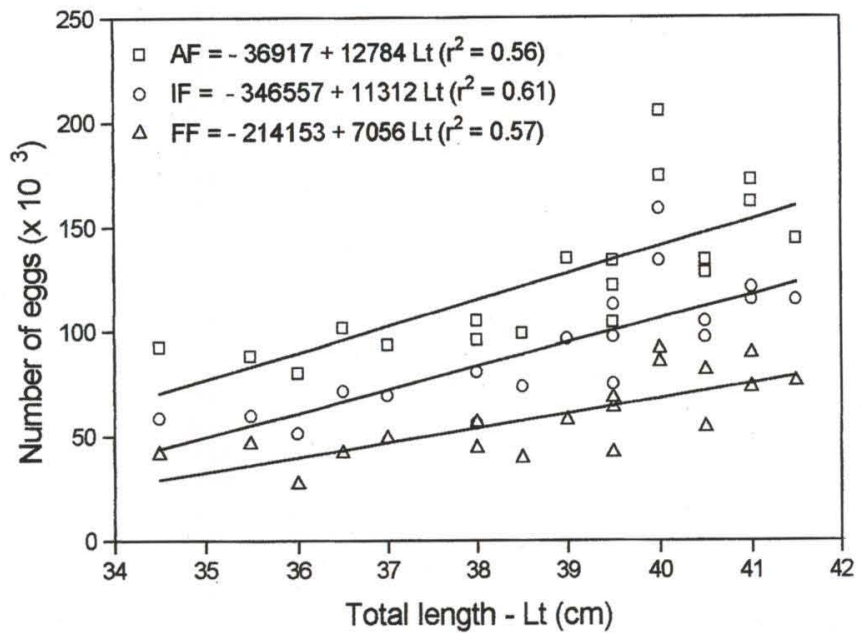

Fig. 2. Linear relationship of absolute fecundity (AF), initial fertility (IF) and final fertility (FF) rates to variations in total length (Lt), obtained simultaneously from 19 Pimelodus maculatus females subjected to hypophysation at Trs Marias Hydrobiology and Hatchery Station during the reproduction cycles of 1995/96 and 1996/97.

The average gonadosomatic index was $5.53 \%$ (range $=4.59-7.19 \%$ ). BASILE-MARTINS et al. (1975) and GoDINHO et al. (1977) recorded average gonadosomatic index values of 6.38 and $7.84 \%$ for $P$. maculatus during the reproductive period. Maximum gonadosomatic index of $9.4 \%$ was recorded by VAZZOLER (1996) from data obtained in the wild. 
The relationship between absolute fecundity, initial fertility and final fertility with body weight and total length are, respectively, shown in figures 1 and 2 . These parameters increased proportionately to the body weight and total length. The values of $\mathrm{r}^{2}$ were improved when these parameters were related to body weight. In GoDINHO et al. (1977), $\mathrm{r}^{2}$ was also higher when fecundity was related to body weight than to total length.

P. maculatus larvae hatched at $394 \pm 9$ hour-degrees (duration $=16.3 \mathrm{~h}$ ) after egg fertilization at water temperature of $24.2 \pm 0.4^{\circ} \mathrm{C}$. The larvae showed vertical movements in the water column and consumed the yolk sac 3.5 to 4 days after hatching. Upon hatching, the larvae had a total length of $2607.84 \pm 45.97 \mu \mathrm{m}$.

ACKNOWLEDGMENTS. The authors acknowledge and thank CODEVASF/CEMIG for the facilities put at their disposal for this study.

\section{REFERENCES}

Basile-Martins, M.A.; H.M. Godinho; N.A. Fenerich \& J.M. BRAMLEY-BARKER. 1975. Influência de fatôres abióticos sobre a maturação dos ovários de Pimelodus maculatus Lac. 1803 (Pisces, Siluroidei). Bol. Inst. Pesca 4 (11): 1-13.

CARDoso, D.M. 1934. Relação gênito-hipofisária e reprodução nos peixes. Arq. Inst. Biol. 5: 133-136.

EsPinAch Ros, A.; V.G. AMUtio; J.P.M. ARCEREdIllo; G. ORTI \& A. NANI. 1984. Induced breeding of the South American catfish, Rhamdia sapo (C. \& V.). Aquaculture 37: 141-146.

FENERICH, N.; H.M. GoDINHO \& J.M. BRAMLEY-BARKER. 1974. Sobre a ocorrência de ovulação de Rhamdia hilarii, Pimelodus maculatus e Salminus maxillosus, em laboratório. Ciência \& Cultura 26 (Supl. 7): 344.

Fowler, H.W. 1951. Os peixes de água doce do Brasil. Arq. Zool. São Paulo 6: 405-625.

Godinho, H.M.; M.A. BAsile-Martins; N.A. Fenerich \& M.Y.NARAhara. 1977. Fecundidade e tipo de desova do mandi, Pimelodus maculatus Lacépède, 1803 (Pisces, Siluroidei). Rev. Brasil. Biol. 37 (4): 737-744.

GodinHo, H.M.; N.A. FENERICH \& M.Y. NARAHARA. 1975. Desenvolvimento embrionário e larval de Rhamdia hilarii (Valenciennes, 1840) (Siluriformes, Pimelodidae). Rev. Brasil. Biol. 38 (1): 151-156.

IhERING, R. vON. 1937. A method for inducing fish to spawn. Proc. Progr. Fish-Cult. 34: 15-16.

IHERING, R. VON \& P. AZEVEDO. 1936. A desova e a hipofisação dos peixes. Evolução de dois Nematognathas. Arq. Inst. Biol. 7 (9): 107-117.

Ihering, R. von; P. Azevedo; C. Pereira JR. \& D.M. Cardoso. 1935. Hypophysis and fish reproduction. Proc. Int. Phys. Congr. 15, Leningrad, Moscow: 211-212.

IHERING, R. vON \& S. WRIGHT. 1935. Fisheries investigations in Northeast Brazil.

Trans. Amer. Fish. Soc. 65: 267-271.

Sato, Y.; E.L. Cardoso; A.L. GodinHo \& H.P. GodinHo. 1996a. Hypophysation 
of the anostomid fish white-piau Schizodon knerii from the Rio São Francisco basin. Arq. Bras. Med. Vet. Zootec. 48 (Supl. 1): 63-70.

1996b. Hypophysation parameters of the fish Prochilodus marggravii obtained in routine hatchery station conditions. Rev. Brasil. Biol. 56 (1): 59-64. VAZZOLER, A.E.A. 1996. Biologia da reprodução de peixes teleósteos: teoria e prática. Maringá, Eduem, 169p.

WOYNAROVICH, E. \& L. HORVÁTH. 1980. The artificial propagation of warm-water finfishes - a manual for extension. FAO Fish. Tech. Pap. 201: 1-183.

Recebido em 20.IV.1998; aceito em 09.IX.1999. 